\title{
Public Speaking Anxiety Reviewed from Self- Efficacy and Audience Response on Students: Systematic Review
}

\author{
Bawinda Sri Lestari ${ }^{1 *}$, Joniarto Parung ${ }^{2}$, Frikson C. Sinambela ${ }^{3}$ \\ ${ }^{1}$ Doctoral Program in Psychology, UBAYA, Surabaya Indonesia \\ ${ }^{2}$ Doctoral Program in Psychology, UBAYA, Surabaya Indonesia \\ ${ }^{3}$ Doctoral Program in Psychology, UBAYA, Surabaya Indonesia \\ *Corresponding author. Email: bawindalestari@gmail.com
}

\begin{abstract}
Students are required to be able to speak publicly. The ability to speak in public will make it easier for students to convey ideas, or suggestions and become a value-added skill for them. Based on literature studies there are several factors that influence public speaking anxiety, including self-efficacy and audience. The study aims to systematically review the relationship between self-efficacy and audience response with public speaking anxiety. The study is expected to enrich previous studies to prevent and address the anxiety of public speaking. Literature searches based on the topic of public speaking anxiety were associated with self-efficacy and audience response, conducted in four electronic databases, Google Scholar, Garuda Portal, ScienceDirect, and SSCI. The search year was from 2009 to 2019; obtained 4,870 articles. Furthermore, selection is carried out using criteria, the time range of publication of articles up to 10 years, quantitative methods, and student subjects. The results obtained 12 quantitative articles that meet the criteria. There were 9 articles stating there was a significant negative correlation between self-efficacy and public speaking anxiety and 3 articles stating there was a significant negative correlation between audience response and public speaking anxiety. This study concluded that to overcome the anxiety of public speaking a person needs high self-efficacy, because the higher a person's selfefficacy, the lower the anxiety. As for the audience response factor, it can be concluded that if the audience response is friendly, pleasant and does not respond negatively, then a speaker will not experience the anxiety of speaking in public, and vice versa.
\end{abstract}

Keywords: Self-efficacy, Audience, Public Speaking Anxiety.

\section{INTRODUCTION}

The ability to speak in public does not belong mainly to public speakers. Everyone has equal opportunity to speak in public, such as Master of Ceremony (MC), Presenter or Moderator, that includes students [1]. Students are required to be able to speak in public, because this will help them to convey ideas, or make suggestions; giving a value-added skill for those concerned. The reality is that many students tend to shy away when asked to speak in public. Bandura [2] mentioned that a person who experiences anxiety would raise concerns and evasive behaviours that affect their performance and academic situation. As much as $73 \%$ of the world's population experiences public speaking anxiety, according to data from The National Institute of Mental Health San Francisco [3]

Research conducted by Spijck [4] in Portugal found that $80 \%$ of students experience anxiety of public speaking on a small or large scale. Meanwhile, research conducted in Malaysia by Raja [5] stated that $75 \%$ of students experience public speaking anxiety. Students tend to avoid and feel anxious when they get the chance to speak in public. Research conducted in Indonesia by Asmidir and Marjohan [6] stated that $42.65 \%$ of students experience anxiety when speaking in public.

Study by Aryadillah [7] found that in Indonesia psychologically both beginners and professionals, who are undergoing and dealing directly with the audience, 
experience speech anxiety. The presence of an audience influences speaker's self-concept who experience anxiety, resulting in the speaker feeling depressed and having an impact on the anxiety of speaking in public. From the data above it shows that public speaking anxiety occurs in all countries, experienced by beginners and professionals on different levels.

Many people shy when asked to speak publicly due to feelings of anxiety. According to McCroskey, Richmond and Gorham [8] individuals who are always evasive, not responsive, and not communicative are considered negative and unprofessional. The anxiety of public speaking will negatively affect aspects of a person's life, from the social, economic, political and academic level. An uncontrolled public speaking anxiety will have an impact on a person's quality of life, stunted career, lack of ability to demonstrate critical thinking skills, while for students the anxiety of public speaking has an impact on academic [8]. According to Griffith and Brosing [9] students who experience anxiety speaking in public will impair their performance in conveying ideas, suggestions, and information as well as during presentations.

\subsection{Public Speaking Anxiety}

According to Leary and Kowalsky [10] public speaking anxiety is one of the most common social anxieties and it is part of social anxiety. McCroskey [11] stated that public speaking anxiety is part of communication apprehension or communication anxiety. The communication in question is public speaking. When a person who experiences anxiety speaks in public, when asked to speak publicly, the reaction that arises is nervous, anxious, worried, and afraid of making mistakes. According to McCroskey [11] public speaking anxiety has several characteristics: a. Internal discomfort. b. Avoidance of communication. c. Withdrawal. d. Excessive communication.

Anxiety is distinguished into 2 categories: state anxiety and trait anxiety [12]. State anxiety is temporary, which is anxiety that occurs when an individual receives a stimulus that is potentially threatening to him or her. Trait anxiety is innate, which is the trait inherent in a person's personality. Public speaking anxiety is a state of anxiety [13], anxiety that occurs in certain situations when speaking in public.

Public speaking anxiety occurs when a person thinks that he or she is not sure capable of controlling the situation he or she is facing, and as a result of it, unable to focus and feeling restless. A person with high selfconfidence and a low level of public speaking anxiety is so opposite, as shown in many studies [6][14][15][16] [17][18][19][20].

\subsection{Self-Efficacy}

According to Bandura, self-efficacy [2] is a person's belief that he or she is capable of thinking, driving motivation and being able to control the situation in order to achieve success. Research conducted by Seri [14], states that self-efficacy has an influence on the anxiety of public speaking of a person. An individual with high self-efficacy the level of anxiety to speak in public is generally low, so vice versa. Research by Deviyanthi [15] showed that a person with high selfefficacy, the lower his or her anxiety of public speaking. This means that self-efficacy has a high influence on a person's anxiety of public speaking.

\subsection{Audience Responses}

Research on audience response results indicate that, negative audience responses to speakers resulted in anxiety rather than positive audience responses [21]. According to the presence of the audience that causes people to experience public speaking anxiety is: 1) the level of formal assessment or evaluation, 2) the audience's attention to the topic and the audience's response to the speaker. It is these three sources of audience attitude that influence a person when speaking in public [21]. Hsu's study [22] showed that a person, who received a negative non-verbal response from the audience, experienced a higher level of anxiety than those who received a positive non-verbal response from the audience. Based on the description above, the anxiety level of public speaking is influenced by selfefficacy and audience. Uncontrolled public speaking anxiety will have an impact on a person's career, and social interaction, incapable of showing his or her abilities as well as for students impacting academic performance.

The purpose of this study is to identify the influence of self-efficacy and audience response with public speaking anxiety. The focus is on reviewing literature article search on student respondents.

\section{METHOD}

The purpose of this literature review is to present findings related to factors that influence public speaking anxiety in students from some of the countries studied. This research is a systematic review using PRISMA (Preferred Reporting Items for Systematic Reviews and Meta-analysis) method, conducted systematically according to the research stage. The steps taken in this Systematic Review are a) Background and Purpose, b) Research Question, c) Searching for the literature, d) Selection Criteria, e) Practical Screen, f) Quality Checklist and Procedures, g) Data Extraction Strategy, h) Data Synthesis Strategy. 
An e-database search was conducted in May 2019; to acquire articles that fit the research needed namely public speaking anxiety. The researcher identified peer review articles in Indonesian and English published in the last 10 years (2009-2019) that can be downloaded in full version, and relevant to anxiety of public speaking. For limitation purposes on articles that the researcher uses in this study are self-efficacy with public speaking anxiety and audience response with public speaking anxiety.

The goal of electronic database search was to get data articles that suit the need, using Google Scholar, Portal Garuda, ScienceDirect, and SSCI. While the keywords used to search for data in this study are "SelfEfficacy" and "Public Speaking Anxiety"; "Audience" and "Public Speaking Anxiety"; "Self-Efficacy" and "Communication Apprehension"; "Self-Efficacy" and "Audience" and "Public Speaking Anxiety"; "Audience" and "Communication Apprehension"; "Self-Efficacy" and "Public Speaking Anxiety"; "Audience" and "Public Speaking Anxiety"; "Self-Efficacy" and "Public Speaking Anxiety"; "Trait Anxiety" and "State Anxiety"; "Positive Thinking" and "Anxiety of Public Speaking" In finding these articles there are no restrictions on the country of origin, only limited by the year of publication, since there has not been any recent research on audience, in the search for data of this article, the data obtained the researcher usage. The articles found were double-checked whether they fit the purpose of the review by reading the abstract. Abstract that has not provided complete information in accordance with the purpose of the study then carry out a more detailed examination of the article, suitable or not with the needs of the study. The inclusion criteria that the researcher set out in this review are articles that already provide appropriate information, with the results of self-efficacy measurements with public speaking anxiety and audiences with public speaking anxiety, whose research subjects are students.

While the application of selection criteria in the article refers to the criteria of inclusion:

a. Peer-reviewed studies (journal articles),

b. Study that focuses on self-efficacy with public speaking anxiety and audience response with public speaking anxiety,

c. The subjects of this study were students.

\section{RESULT}

\subsection{Number and Source of Articles, which include Inclusion Criteria}

Based on search results using Google Scholar, Portal Garuda, ScienceDirect, SSCI, obtained 4,870 articles of public speaking anxiety. An article search was conducted in May 2019. The population in this study was articles published in national and international journals. The samples in the study were articles published in national and international journals that discussed self-efficacy with public speaking anxiety, audience responses to public speaking anxiety that met inclusion criteria. The inclusion criteria in this study are: 1) Research articles published in 2009-2019, 2) Types of research are quantitative, 3) Research studies that discuss self-efficacy with anxiety of public speaking and audience response with public speaking anxiety, 4) Research study conducted in Indonesia and Outside Indonesia, 5) Independent variables are self-efficacy and audience response, 6) Dependent variables is public speaking anxiety, 7) The research subjects are students, 8) Respondents to the research article showed that there were 1,860 articles. A total of 89 articles were selected based on the researcher's objectives, namely those that discussed self-efficacy with public speaking anxiety obtained 89 articles and which discussed audience responses with public speaking anxiety obtained 58 articles. The next step is conducting an abstract review of the 147 articles selected, 112 articles issued because they do not include quantitative, and 35 articles entered for the next step, which is full text. Full text search of 35 selected articles, 23 articles issued because they do not fall under inclusion criteria. A total of 12 selected articles were entered for analysis. There are 9 selfefficacy articles with public speaking anxiety, 3 articles of audience response with anxiety in public, as summarised in Figure 1.

\subsection{Self-Efficacy with Public Speaking Anxiety}

Research linking self-efficacy to public speaking anxiety, and student subjects conducted by a number of studies $\quad[14][15][16][17][18][19][23][24], \quad$ obtained different correlation results. From several journal articles obtained findings that self-efficacy there is a negative relationship that significant anxiety with public speaking. Studies conducted in Indonesia and America had the highest correlation with values $(r=-0.725, p=$ $01)$ and the lowest $(\mathrm{r}=-0.252, \mathrm{p}=.01)$. Research conducted by Deviyanthi [15] obtained correlation value $\mathrm{r}=-0.725$, [16] $\mathrm{r}=-0.513$, [23] $\mathrm{r}=-0.41$, [19], $\mathrm{r}=-0.658,[20] \mathrm{r}=-0.509,[24] \mathrm{r}=-0.224,[17] \mathrm{r}=-0.456$, [18] $\mathrm{r}=-0.162$, [14] $\mathrm{r}=0.203$. From the correlation values obtained showed a difference in correlation results between researchers with each other, there are high correlation values, yet there are low correlation 
values, even the results of the research conducted by Seri [14] found there was no relationship between selfefficacy and anxiety public speaking.

4,870 articles on anxiety found from Google

Scholar, Garuda Portal, ScienceDirect, and

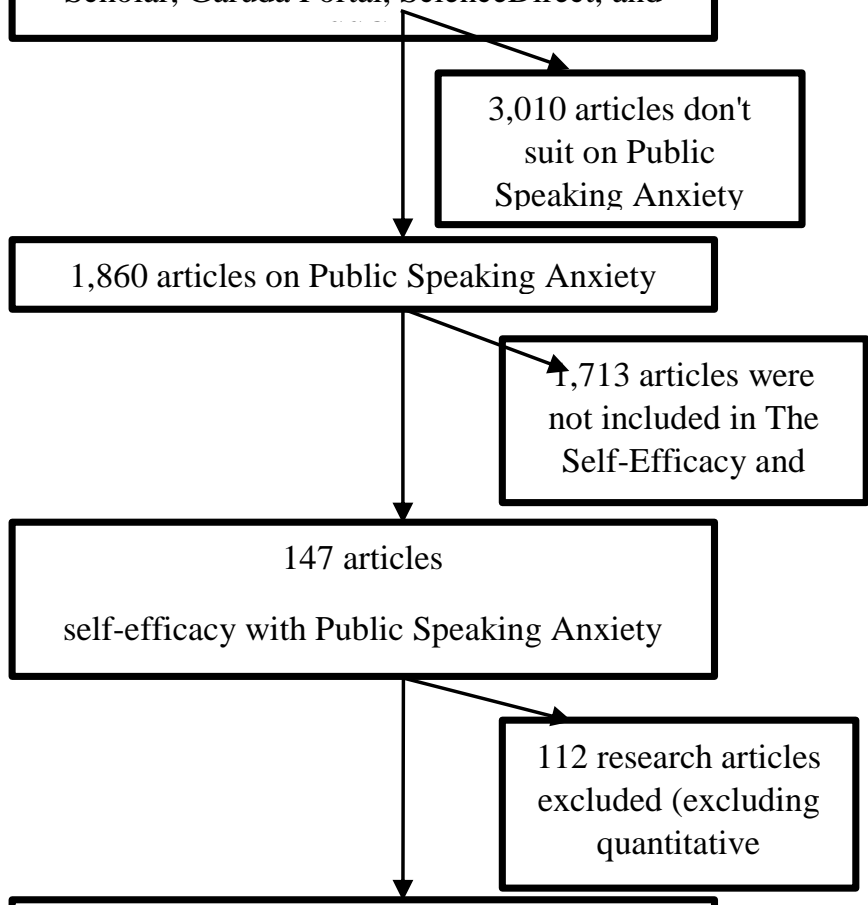

35 researched articles were included in full text review

23 researched articles exclusivity (does not meet

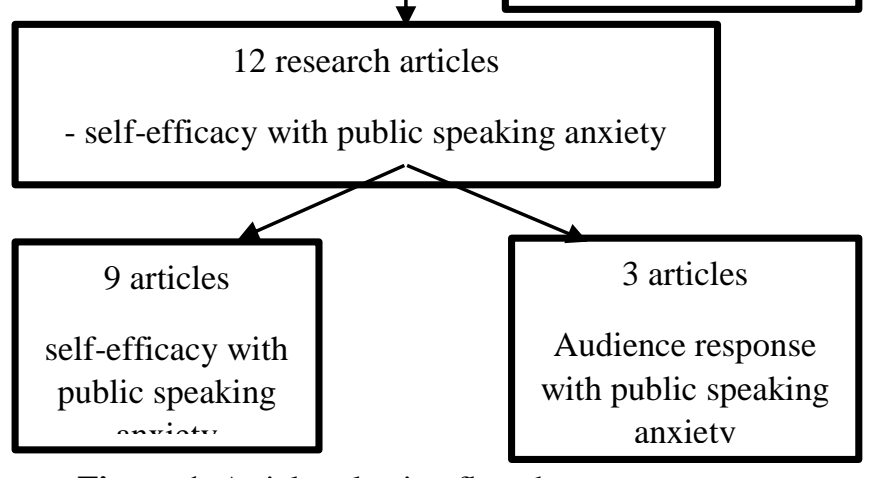

Figure 1. Article selection flowchart

\subsection{Audience Response to Public Speaking Anxiety}

Several studies [21][22] showed that audience and anxiety of public speaking from 3 countries: Canada, America and London showed there was a significant negative relationship between audiences with public speaking anxiety. Research conducted by Peter et al.
[21] in Canada found that speaker was more anxious in front of a low-interest audience, with a value (M $=30.05)$, than a high-interest audience with a value $(\mathrm{M}=$ 27.99). Speakers are more anxious when they get a formal evaluation from the audience, with a value $(\mathrm{M}=$ 27.24) than those who do not get an evaluation from the audience with a value $(\mathrm{M}=25.75)$. Audiences who are not responsive to speakers are more anxious about the value $(\mathrm{M}=31,45)$, while a responsive audience obtained a value $(\mathrm{M}=24,03)$ that is not to worry the speaker. Hsu's [10] research conducted in America, negative audience response with public speaking anxiety correlation value $r=-0.27$.

Another finding that influences public speaking anxiety is self-efficacy, positive thinking with public speaking anxiety, with a value $(\mathrm{f}=12,492 \mathrm{R}=0.188)$. Mindset is very helpful for a person in overcoming mood-related problems, such as depression, anxiety, anger, panic, jealousy, guilt and shame. A positive mindset (positive thinking) was helpful in overcoming the anxiety of public speaking.

Another study that was also obtained was an article that analysed the perception of communication competence with public speaking anxiety, with a value $(\mathrm{r}=-0.66, \mathrm{p}=.01)$ meaning that a person who has a perception of competence towards him, then the level of anxiety in public speaking is generally lower than that of the not. The perception of competence in question is the perception of communication competence, which is related to public speaking. The summary was described in Table 1.

\subsection{Conclusion}

Self-efficacy has a significant negative influence on public speaking anxiety, (internal factors), from external factors the audience response has a significant negative influence on public speaking anxiety, low-interest audiences, low responsiveness and high evaluation that trigger anxiety in the speaker, while a pleasant, friendly and familiar audience makes the speaker calmer and does not experience anxiety. To overcome the anxiety of public speaking it takes high self-efficacy and a positive response of the audience to the speaker.

Two factors influence public speaking anxiety, from internal and external. This study only limited to articles about public speaking anxiety and communication apprehension, anxiety of public speaking, self-efficacy, audience. This study showed that the majority of articles are still limited to linking individual factors with public speaking anxiety, external factors with public speaking anxiety.

Further research, preferably should combine individual and external factors with public speaking 
anxiety. Measurement on self-efficacy variables should focus on positive thinking, communication competency perception and audience response. Limited studies in Indonesia addressing external factors of audiences with public speaking anxiety call on further studies that should not limit articles to specific language, public speaking anxiety, communication apprehension, selfefficacy and audience as researchers want to know the extent of the relationship between variable to anxiety speaking in public. It is important to expand further

Table 1. Table Review

\begin{tabular}{|c|c|c|c|}
\hline Researcher & $\begin{array}{l}\text { Country of } \\
\text { origin }\end{array}$ & Sample (n) & Purpose \\
\hline [21] & Indonesia & $\begin{array}{l}52 \text { students of D-IV study } \\
\text { program }\end{array}$ & $\begin{array}{l}\text { Looking for the relationship between self-efficacy and } \\
\text { anxiety when providing counseling }\end{array}$ \\
\hline [15] & Indonesia & $\begin{array}{l}175 \text { people }(33 \text { men and } \\
142 \text { women })\end{array}$ & $\begin{array}{l}\text { Looking for the relationship between self-efficacy and } \\
\text { communication anxiety in presenting assignments in front } \\
\text { of the class. }\end{array}$ \\
\hline [16] & Indonesia & $\begin{array}{c}\text { Psychology faculty students } \\
\text { of the Muhammadiyah } \\
\text { University of Aceh } \\
\text { semesters I, III, and V. }\end{array}$ & $\begin{array}{l}\text { Looking for the relationship between self-efficacy and } \\
\text { public speaking in students }\end{array}$ \\
\hline [17] & Indonesia & 136 students of class 2012 & $\begin{array}{l}\text { Looking for the relationship between self-efficacy and } \\
\text { speaking anxiety experienced by students in the Biology } \\
\text { seminar course. }\end{array}$ \\
\hline [18] & Indonesia & $\begin{array}{c}136 \text { second semester } \\
\text { students from four speaking } \\
\text { classes for the } 2012 / 2013 \\
\text { school year. }\end{array}$ & $\begin{array}{l}\text { Observe the interaction and its effect between speaking } \\
\text { self-efficacy and gender in speaking activities (speaking) }\end{array}$ \\
\hline$[23]$ & Washington & $\begin{array}{c}837 \text { undergraduate } \\
\text { students in Western } \\
\text { University's basic } \\
\text { communications course. }\end{array}$ & $\begin{array}{c}\text { To find out the relationship between interpersonal } \\
\text { communication apprehension (ICA) is more related to self- } \\
\text { efficacy }\end{array}$ \\
\hline$[25]$ & Indonesia & 100 new students & $\begin{array}{l}\text { Looking for differences in the degree of anxiety between } \\
\text { new students at FIKES and Non-FIKES / FEISHum and the } \\
\text { difference in degrees of depression between new students at } \\
\text { FIKES and Non-FIKES / FEISHum. }\end{array}$ \\
\hline [19] & Indonesia & $\begin{array}{c}\text { Bunda Mulia University } \\
\text { Psychology Student, class } \\
\text { of 2008-2011. }\end{array}$ & $\begin{array}{c}\text { Knowing the relationship between self-efficacy and } \\
\text { public speaking anxiety among students of the Psychology } \\
\text { Study Program at Bunda Mulia University in North Jakarta. }\end{array}$ \\
\hline$[20]$ & Indonesia & $\begin{array}{c}222 \text { students from all } \\
\text { faculties at Esa Unggul } \\
\text { University, class } 2011-2013 \\
\text { (160 students and } 62 \\
\text { students). }\end{array}$ & $\begin{array}{l}\text { This is to determine the relationship between self-efficacy } \\
\text { and anxiety at the time of presentation to students }\end{array}$ \\
\hline [26] & Turkey & $\begin{array}{l}95 \text { level } 1 \text { students taking } \\
\text { communication science } \\
\text { courses and level } 2 \text { students } \\
\text { taking psychology courses. }\end{array}$ & $\begin{array}{l}\text { This is to determine the relationship between public } \\
\text { speaking anxiety and who is the audience (audience). }\end{array}$ \\
\hline$[21]$ & Canada & $\begin{array}{c}121 \text { second year } \\
\begin{array}{c}\text { University psychology class } \\
\text { students }\end{array}\end{array}$ & $\begin{array}{l}\text { To research potential sources of audience-derived public } \\
\text { speaking anxiety. }\end{array}$ \\
\hline [27] & America & $\begin{array}{c}196 \text { Students ( } 85 \text { male, } \\
109 \text { female, and } 2 \text { who did } \\
\text { not indicate their gender), } \\
\text { ranged in age from } 18 \text { to } 64 \\
\text { years }\end{array}$ & $\begin{array}{c}\text { Examining the relationship between public speaking } \\
\text { anxiety, perceived competence, and audience perceptions } \\
\text { before and after the speech. }\end{array}$ \\
\hline [24] & Indonesia & $\begin{array}{c}90 \text { students of the study } \\
\text { program of communication } \\
\text { science at the University of } \\
X \text { in Jakarta, class of 2014- } \\
2015\end{array}$ & $\begin{array}{l}\text { Look for the relationship between positive thinking and } \\
\text { self-efficacy and public speaking anxiety. }\end{array}$ \\
\hline
\end{tabular}


studies to gain insights about fear of public speaking, fear communication.

\section{AUTHORS' CONTRIBUTIONS}

BSL determines the idea and writes this scientific work from start to end. She also conducts referral searches according to the directions and topics that become the basic idea of the research. JP and FCS play an important role in providing inputs, as well as providing references, evaluating the results, reviewing and writing the manuscript.

\section{ACKNOWLEDGMENTS}

The researcher would like to convey her highest appreciation for the cooperation, ideas, and suggestions of all professors, colleagues, friends and the students of interest.

\section{REFERENCES}

[1] C. Sirait. The power of public speaking. Jakarta: PT. Gramedia Pustaka Utama, 2013.

[2] A. Bandura. Self-efficacy - The exercise of control (fifth edition). New York: W.H. Freeman \& Company, 1997.

[3] National Social Anxiety Center, Social anxiety. 2017. Available from https://nationalsocialanxietycenter.com/2017/08/13/t hriving-college-student-social-anxiety/

[4] B. Spijck. Overcoming fear of public speaking. International Coach Academy. 2011. Available from https://coachcampus.com/coach-portfolios/researchpapers/joana-reis-anapproach-for-coaches/

[5] Raja. Anxiety level in students of public speaking: causes and remedies. Int J Educ Dev. 4(1) (2013) 23. DOI: $10.1 .1 .632 .176 \&$ rep=rep1\&type $=$ pdf

[6] Asmidir., Ririn., Marjohan, Hubungan Antara Keterampilan Komunikasi Dengan Kecemasan Berbicara Di Depan Umum. J Il Kons. 2(1) (2013) DOI: $10.24036 / 02013211203-0-00$

[7] Aryadillah, Kecemasan dalam Public Speaking (studi kasus pada presentasi makalah mahasiswa). J Cakr.17(2) (2017) DOI: 10.31294/jc.v17i2

[8] J.C. McCroskey., V.P. Richmond., J.S. Gorham, The Relationship Between Selected Immediacy Behaviors and Cognitive Learning. Comm Yearbk. 10 (198) 574-59
[9] W.T. Griffith., J.W. Brosing. The Physics of Everyday Phenomena: A Conceptual Introduction to Physics. The McGraw-Hill Companies. 2009.

[10] M.R.Leary, R.M. Kowalski. Social anxiety. New York: The Guilford Press. 1995

[11] McCroskey, The communication apprehension Perspective. [On-line]. Available from http:/ www jamescmccroskey.com/bookchapters/003_ 1984_c1. Pdf. Access date: December 16, 2013.

[12] C.D. Spielberger. Current trends in theory and research on anxiety. Academic Press, Inc. 1972. DOI: 10.1016/B978-0-12-657401-2.50008-3

[13] J.C. McCroskey. Oral communication apprehension: A summary of recent theory and research. Hum. Commun. Res. (1977) 78-96. DOI: 10.1111/j.1468-2958.1977.tb00599.x

[14] U. Seri. Self-efficacy terhadap kecemasan dalam praktek penyuluhan kesehatan di lahan praktek mahasiswa. J Vok Kes, 2(1) (2016) 73-77. DOI: $10.30602 / j v k . v 2 i 1.58$

[15] N.M.F. Deviyanthi. Hubungan antara self-efficacy dengan kecemasan komunikasi dalam mempresentasikan tugas di depan kelas. J Psi Udayana, 3(2) (2016). DOI: 10.24843/JPU.2016.v03.i02.p16

[16] D. M. Barmawi. Self-efficacy dan kecemasan berbicara di depan umum pada mahasiswa Fakultas Psikologi Universitas Muhamadiyah Aceh. J Ilmiah Psikologi An Nafs. 3(1) (2013).

[17] H. Astina., M.M.Ibrahim., Muchlisah. Hubungan antara self-efficacy dengan kecemasan berbicara mahasiswa pada mata kuliah seminar biologi Jurusan Pendidikan Biologi UIN Alauddin Makassar. J Biotek. 4(2) (2016). DOI: $10.24252 /$ jb.v4i2.1792

[18] Dasmo., H. Sundari. The effect of speaking selfefficacy and gender in speaking activities of PGRI Indraprasta University. Lang. Lit. 14(2) (2014)

[19] D. Kasih, D., S. Sudarji. Hubungan self-efficacy terhadap kecemasan berbicara di depan umum pada Mahasiswa Program Studi Psikologi Universitas Bunda Mulia. J Psibernetika. 5(2) (2012)

[20] W.S. Riani., Y.A. Rozali. Hubungan antara selfefficacy dan kecemasan presentasi pada mahasiswa Universitas Esa Unggul. J Psiko, 12(1) (2014). 
[21] P.D. MacIntyre., K.A. Thivierge., J.R. MacDonald. The effect of audience interest, responsiveness, and evaluation on public speaking anxiety and related variables. Commun. Res. Rep. 14(2) (2013) 157-168. DOI: $10.1080 / 08824099709388657$

[22] C-F. Hsu. The relationships of trait anxiety, audience nonverbal feedback, and attributions to public speaking state anxiety. Commun. Res. Rep. 26(3) (2009) 237-246. DOI: $10.1080 / 08824090903074407$

[23] H. Tim., C. Noelle. The Relation details, including instructions for author and subscription information. Commun. Res. Rep. (2009) 131-135

[24] A.W. Christiningsih., R. Widyana. Hubungan antara berpikir positif dan efikasi diri dengan kecemasan berbicara di depan umum pada mahasiswa Program Studi Ilmu Komunikasi Universitas X Jakarta, Jur. Psikol. 13 (2017) 1425.

[25] R.Y. S. Subardjo. Perbedaan tingkat kecemasan pada mahasiswa baru di Fakultas Ilmu Kesehatan dan non Fakultas Ilmu Kesehatan Universitas 'Aisyiyah Yogyakarta. Program Studi UIN Sunan Kalijaga, Jur. Psikol Integratif. 6(1) (2018).

[26] P.D. MacIntyre, K.A. Thivierge. The effect of audience interest, responsiveness, and evaluation on public speaking anxiety and related variables. University of South Dakota. 1997.

[27] P.D. MacIntyre, J.R. MacDonald. Public speaking anxiety: Perceived competence and audience congeniality. University of Massachusetts, Amherst. 1998. 